\title{
ONIOM Method Characterization of Hydrogen Bonding Sites of Mycolactone A/B, a Buruli Ulcer Toxin
}

\author{
Kadjo François Kassi, Mamadou Guy-Richard Koné, Sopi Thomas Affi, Nahossé Ziao* \\ Laboratoire de Thermodynamique et de Physico-Chimie du Milieu, UFR SFA, Université Nangui Abrogoua, Abidjan, \\ Côte-d'Ivoire \\ Email: *nahosse_ziao@yahoo.fr
}

How to cite this paper: Kassi, K.F., Koné, M.G.-R., Affi, S.T. and Ziao, N. (2017) ONIOM Method Characterization of Hydrogen Bonding Sites of Mycolactone A/B, a Buruli Ulcer Toxin. Computational Chemistry, 5, 103-112.

https://doi.org/10.4236/cc.2017.53009

Received: May 23, 2017

Accepted: July 8, 2017

Published: July 11, 2017

Copyright $\odot 2017$ by authors and Scientific Research Publishing Inc. This work is licensed under the Creative Commons Attribution International License (CC BY 4.0). http://creativecommons.org/licenses/by/4.0/

\begin{abstract}
Mycolactone molecules are responsible of Buruli ulcer disease. In this work, we are interested in the geometric, energetic and spectroscopic characterization of the hydrogen bonding interactions in mycolactone $\mathrm{A} / \mathrm{B}$, using quantum chemical method, especially ONIOM(HF/6-311+G(d,p):AM1) and ONIOM (B3LYP/6-311+G(d,p):AM1) levels. ONIOM two layers method has been used because mycolactones compounds are very large, taking into account diffuse and polarization functions are important whenever the matter is intermolecular interactions. Geometric, energetic and spectroscopic parameters of hydrogen bonding reaction on each of the nine oxygen heteroatoms of mycolactone $\mathrm{A} / \mathrm{B}$ have revealed that the $\mathrm{O}_{5} \mathrm{sp}^{2}$ heteroatom is far away the hydrogen bonding site. The identification of such a site constitutes a tool for working out a methodology for the annihilation of the destruction effects of mycolactones.
\end{abstract}

\section{Keywords}

Hydrogen Bonding, Mycobacterium ulcerans, Mycolactone, ONIOM, Quantum Chemistry

\section{Introduction}

Buruli ulcer is a disease caused by Mycobacterium ulcerans, a microorganism belonging to the family of bacteria responsible for tuberculosis and leprosy [1]. Longtime neglected, this disease that prevails in tropical and subtropical humid countries, has increased in West Africa since 1980 [2]. This situation led the World Health Organization (WHO) to classify this disease as emerging and to recognize it as a public health and development problem [3]. Mycobacterium ulcerans secretes a toxin called mycolactone, responsible for extremely deep tis- 
sue damage, because of its cytotoxic and immunosuppressive properties. Nowadays, six (06) different natural molecular structures of mycolactones named A/B, C, D, E, F and G, have been isolated [4]. The mycolactone is constituted of a lactone ring linked to two lateral chains. Especially, the form A/B is the subject of this study (Figure 1).

Despite the progress in medical management, the therapeutic arsenal against Buruli ulcer remains limited [5]. Indeed, antibiotic therapy and restorative surgery remain the reference treatment, with high cost and numerous relapses $(16 \%$ to $28 \%$ ), in case of serious infection [6]. The mode of the toxin's action remains unknown. The relationship between mycolactone and the proteins responsible for the appearance of Buruli ulcer are related to the conformation of the molecules and their intermolecular interactions. Hydrogen bond is one of the most important inter-molecular interactions involved in supramolecular chemistry, protein-ligand interactions [7] [8] and especially crystal engineering [9] [10]. Polyfunctional molecules, generally, comprise several heteroatoms which are capable to receive Hydrogen bonds. This work, part of Buruli ulcer control program, focuses on mycolactones A/B. It aims to determine, by quantum chemical methods, some physicochemical properties of these mycolactone molecules, in particular, geometric and energetic parameters of the hydrogen bonds established on the heteroatoms, in order to determine hydrogen bonding site. Final aim is to propose an experimental methodology of the annihilation of the destructive effects of mycolactone A/B.

\section{Experimentation Section}

\subsection{Computational Details}

Mycolactone A/B possesses nine (09) heteroatoms, all those are $\mathrm{sp}^{2}$ or $\mathrm{sp}^{3}$ hybridized oxygen atoms, shown in red color at a $3 \mathrm{D}$ molecular structure of mycolactone $\mathrm{A} / \mathrm{B}$ (Figure 2). Heteroatoms are numbered from 1 to 9 and these numbers will also correspond respectively to the names of the different hydrogen bond complexes.

ONIOM method, developed by Morokuma et al. [11], is used because of the

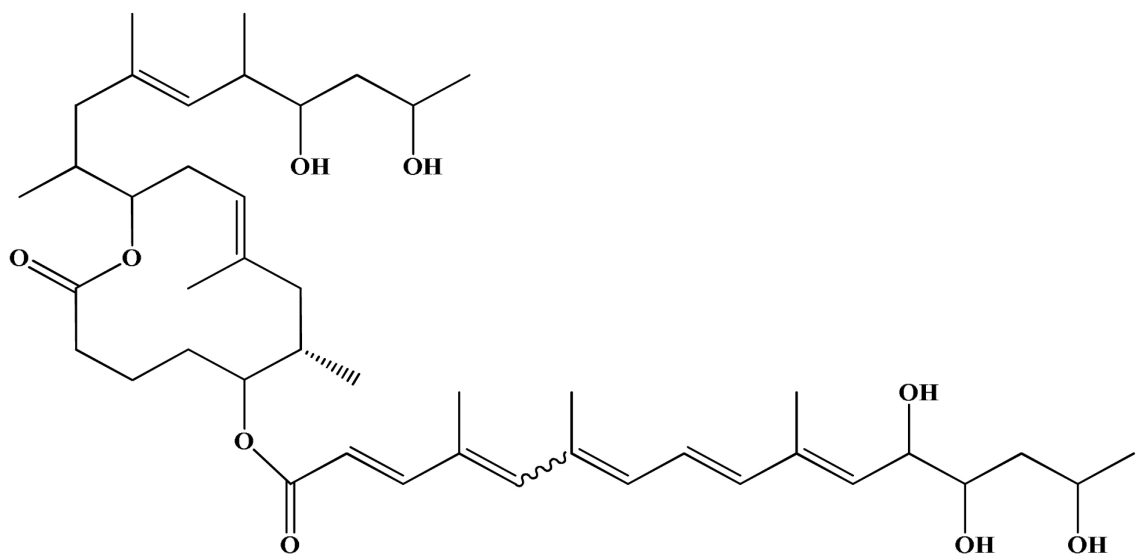

Figure 1. 2D structure of mycolactone A/B. 


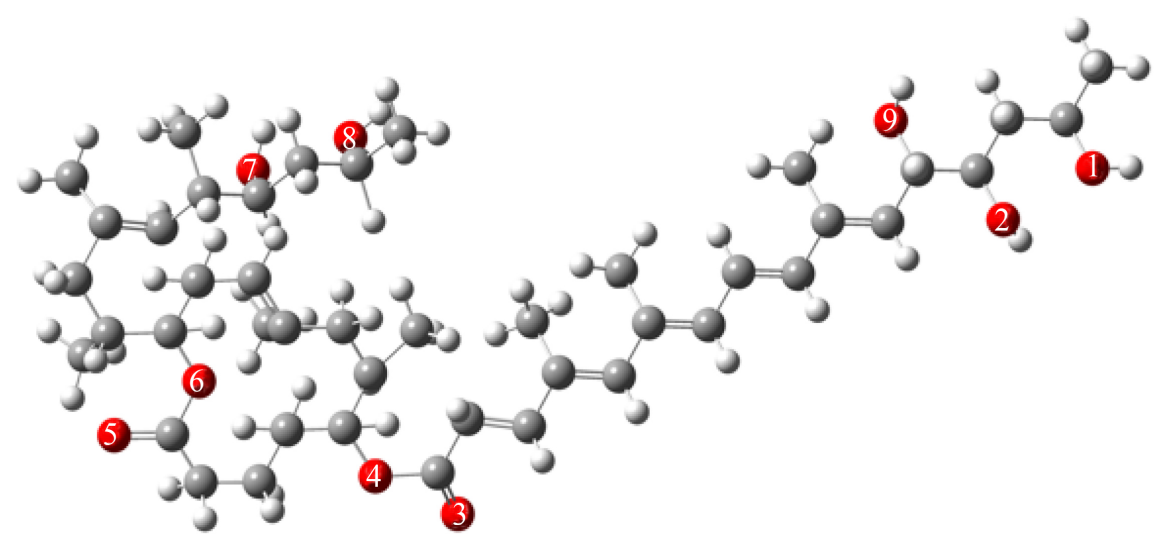

Figure 2. 3D Molecular structure of mycolactone A/B (visualized with Gauss View 5.0 software).

high number of atoms in mycolactone A/B. It consists of cutting the studied system into several layers, each of the layers being treated at a different calculation level. It therefore allows to describe precisely the part of the system which has particular interest for the study, called the internal layer, and to describe in a less precise manner the rest of the system, called the outer layer or the environment. ONIOM method permits to obtain the energy of the real system at a high level of computation called high level, $E$ (high, real), by means of extrapolation according Equation (1), where $E$ (low, real) is the energy of the real system at the low calculation level, $E$ (high, model) the energy of the model system at the higher calculation level, and $E$ (low, model) the energy of the model system at the low calculation level. An example of description of the ONIOM two layers in mycolactone A/B is shown in Figure 3.

$$
E(\text { high }, \text { real })=E(\text { low, real })+E(\text { high }, \text { model })-E(\text { low }, \text { model })
$$

All calculations were performed, using Gaussian 03 software [12] at the ONIOM $(\mathrm{HF} / 6-311+\mathrm{G}(\mathrm{d}, \mathrm{p}): A M 1)$ and $\mathrm{ONIOM}(\mathrm{B} 3 \mathrm{LYP} / 6-311+\mathrm{G}(\mathrm{d}, \mathrm{p}): \mathrm{AM} 1)$. The presence of diffuse and polarization functions in the basis sets is important in order to take into account the lone pairs of the heteroatoms, as well as intermolecular interactions.

\subsection{Geometry Optimization}

Nine hydrogen bond complexes were constructed on each of the oxygen heteroatoms, a water molecule being the probe, as Hydrogen Bonding Donor. Such hydrogen bond can be characterized by geometric parameters (Figure 4).

Before optimization, for all complexes, the angle of the linearity $\alpha$ has been set at $180^{\circ}$ and the angle of the directionality $\beta$, at $109.5^{\circ}$ for $\mathrm{sp}^{3}$ hybridized oxygen and $120^{\circ}$ for $\mathrm{sp}^{2}$ hybridized oxygen. According to Gillespie's V.S.E.P.R (Valence Shell Electron Pair Repulsion) theory (Figure 5), the distance $d$ between an oxygen atom of mycolactone and a hydrogen atom of the probe is set at $2 \AA$. These values correspond respectively to the angles and the minimum approach distance of the hydrogen bond [14]. 


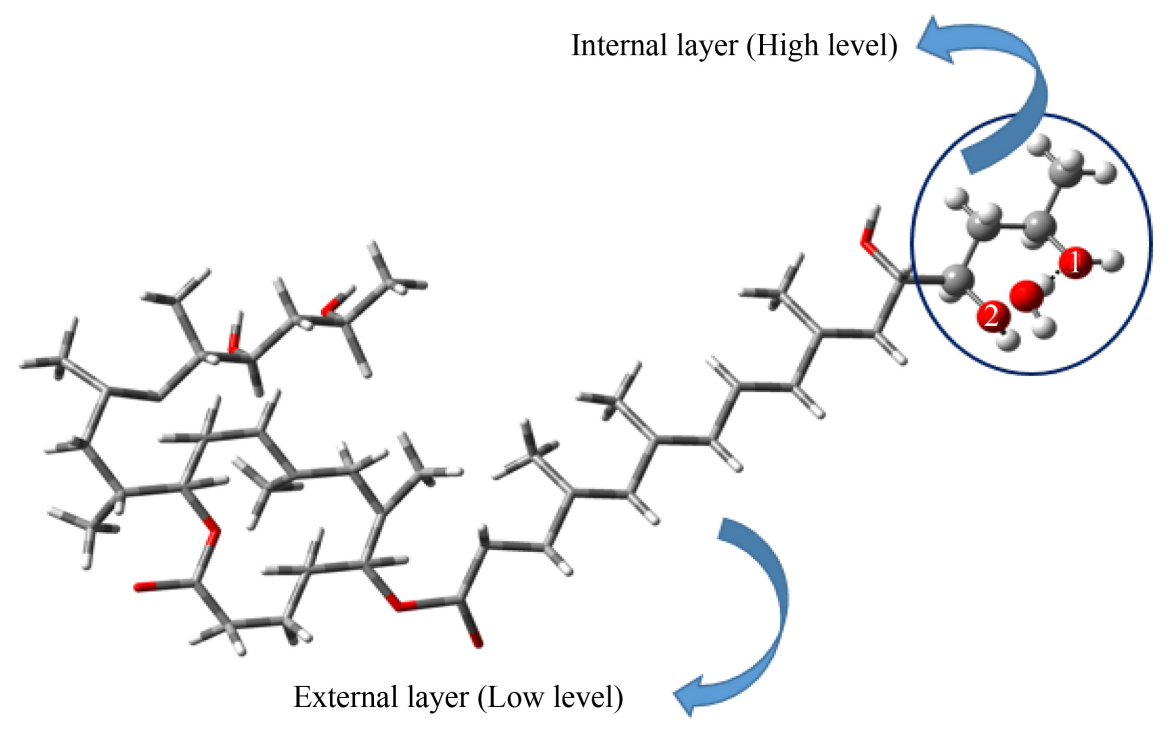

Figure 3. Description of a model for cutting a complex of mycolactone A/B according ONIOM method (Figure from gaussview software).

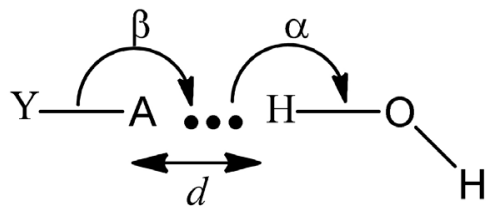

Figure 4. Geometric parameters $\alpha, \beta$ and $d$ describing hydrogen bond [13].

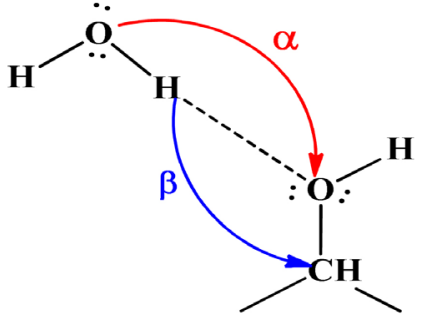

sp $^{3}$ Oxygen

$\alpha=180^{\circ} ; \beta=109.5^{\circ}$

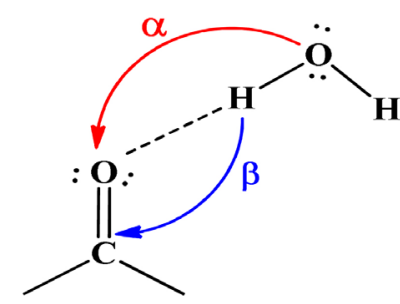

$\mathbf{s p}^{2}$ Oxygen

$\alpha=180^{\circ} ; \beta=120^{\circ}$

Figure 5. Definition of linearity and directionality angles describing hydrogen bond.

\subsection{Energetic Parameters}

Hydrogen bonding between a donor molecule $\mathrm{H}-\mathrm{X}$ and an acceptor molecule $\mathrm{Y}-\mathrm{A}$ occurs according reaction 2 . The Hydrogen bond complex $\mathrm{Y}-\mathrm{A} \cdots \mathrm{H}-\mathrm{X}$ is the product. The variation in electronic energy, at $0 \mathrm{~K}$, is given by Equation (3):

$$
\begin{gathered}
\mathrm{Y}-\mathrm{A}+\mathrm{H}-\mathrm{X} \rightarrow \mathrm{Y}-\mathrm{A} \cdots \mathrm{H}-\mathrm{X} \\
\Delta E_{\text {elec }}^{0}=E_{\text {elec }}^{0}(\mathrm{Y}-\mathrm{A} \cdots \mathrm{H}-\mathrm{X})-\left[E_{\text {elec }}^{0}(\mathrm{Y}-\mathrm{A})+E_{\text {elec }}^{0}(\mathrm{H}-\mathrm{X})\right]
\end{gathered}
$$

The internal energy, at $298.15 \mathrm{~K}$, corresponds to the sum of the electronic, ro- 
tational, translational and vibrational contributions, so that it' variation can be written according Equation (4):

$$
\Delta E_{298}^{0}=\Delta E_{\text {electronic }}^{0}+\Delta E_{\text {rotation }}^{0}+\Delta E_{\text {translation }}^{0}+\Delta E_{\text {vibration }}^{0}
$$

Geometry optimization of both reactants and products, gives access to all contributions (including nuclear repulsion energies). In ideal gas approximation, rotational and translational contributions are given according Equation (5):

$$
\Delta E_{\text {translation }}^{0}=\Delta E_{\text {rotation }}^{0}=-\frac{3}{2} R T
$$

$\Delta E_{\mathrm{vibration}}^{0}$ includes ZPVE (Zero Point Vibrational Energy) energy, i.e. lowest vibrational level energy, due to $3 N-6$ normal vibrational modes ( $3 N-5$ for the linear molecules), each with frequency $v_{i}$, up to $N$ kernels at $0 \mathrm{~K}$. Taking into account the extra energy due to vibrational levels population during temperature rising from 0 to $298.15 \mathrm{~K}$, leads to Thus, Equation (6), from which the term $\Delta E_{\text {vib.thermal }}^{0}$ can be drawn:

$$
E_{\text {vib.thermal }}^{0}=R \sum_{i=1}^{3 N-6} \frac{h v_{i} / k}{\mathrm{e}^{h v_{i} / 298 \mathrm{~K}}-1}
$$

As a result, internal energy variation at $298.15 \mathrm{~K}$ is given by Equation (7):

$$
\Delta E_{298 \mathrm{~K}}^{0}=\Delta E_{\text {elec }}^{0}+\Delta \mathrm{ZPVE}+\Delta E_{\text {vib.thermal }}^{0}-3 R T
$$

Enthalpy and free enthalpy variations, At 298.15 K, enthalpy and free enthalpy are respectively given by Equations (8) and (9), and entropy variation, by Equation (11):

$$
\begin{gathered}
\Delta H_{298 \mathrm{~K}}^{0}=\Delta E_{298 \mathrm{~K}}^{0}-R T \\
\Delta G_{298 \mathrm{~K}}^{0}=\Delta H_{298 \mathrm{~K}}^{0}-T \cdot \Delta S_{298 \mathrm{~K}}^{0}
\end{gathered}
$$

where

$$
\Delta S_{298 \mathrm{~K}}^{0}=\Delta S_{\text {trans }}^{0}+\Delta S_{\text {rot }}^{0}+\Delta S_{\text {vib }}^{0}
$$

\subsection{Spectroscopic Parameters}

Spectroscopic descriptors can serve as Hydrogen bond scale. The X-H bond linking the donor atom $\mathrm{X}$ and the hydrogen atom $\mathrm{H}$ increases or decreases according Hydrogen bond's strength. Therefore the stretch vibration wave-number can be measured. When the donor is a water molecule, the displacement $\Delta v(\mathrm{O}-\mathrm{H})$ is the scale, and respectively for $\mathrm{sp}^{2}$ and $\mathrm{sp}^{3}$ oxygen atoms, this scale is defined according Relations (11) and (12):

$$
\begin{aligned}
& \Delta v(\mathrm{O}-\mathrm{H})=v_{s}(\mathrm{O}-\mathrm{H})_{\text {free }}-v\left(\mathrm{O}-\mathrm{H} \cdots \mathrm{O}_{\mathrm{sp}^{2}}\right)_{\text {complex }} \\
& \Delta v(\mathrm{O}-\mathrm{H})=v_{s}(\mathrm{O}-\mathrm{H})_{\text {free }}-v\left(\mathrm{O}-\mathrm{H} \cdots \mathrm{O}_{\mathrm{sp}^{3}}\right)_{\text {complex }}
\end{aligned}
$$

At ONIOM(HF/6-311+G(d,p):AM1) and ONIOM(B3LYP/6-311+G(d,p):AM1) levels, frequencies of vibrator $v_{s}(\mathrm{O}-\mathrm{H})_{\text {free }}$ equal respectively, $4242.25 \mathrm{~cm}^{-1}$ and $3923.88 \mathrm{~cm}^{-1}$. 


\section{Results and Discussion}

\subsection{Geometric Parameters}

All geometry optimizations succeeded at the two levels of computation. Examples of initial guess geometry and then optimized geometries of two hydrogen bond complexes are shown in Figure 6. Geometric parameters are given in Table 1 .

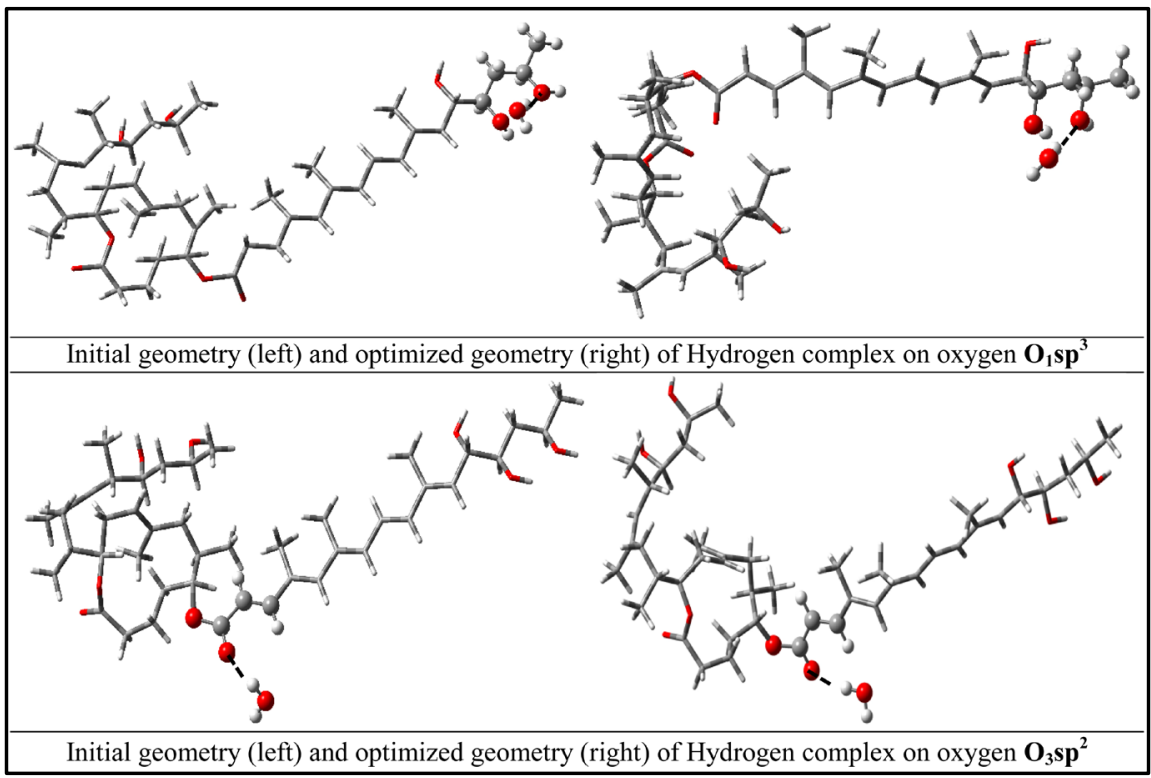

Figure 6. Examples of non-optimized and optimized geometries of Hydrogen bond complexes computed at ONIOM(B3LYP/6-311+G(d,p):AM1) level.

Table 1. Geometric parameters of Hydrogen bond complexes of mycolactone A/B.

\begin{tabular}{lcccccc}
\hline & \multicolumn{3}{c}{ ONIOM } & \multicolumn{3}{c}{ ONIOM } \\
& $\alpha\left(^{\circ}\right)$ & $B\left(^{\circ}\right)$ & $d(\AA)$ & $\alpha\left(^{\circ}\right)$ & $B\left(^{\circ}\right)$ & $d(\AA)$ \\
\cline { 2 - 6 } & 135.90 & 92.80 & 4.10 & 132.70 & 94.58 & 3.86 \\
$\mathrm{O}_{1} \mathrm{sp}^{3}$ & 161.97 & 109.04 & 2.02 & 163.30 & 108.40 & 1.88 \\
$\mathrm{O}_{2} \mathrm{sp}^{3}$ & 163.20 & 115.00 & 2.09 & 162.10 & 127.00 & 1.91 \\
$\mathrm{O}_{3} \mathrm{sp}^{2}$ & 129.71 & 68.08 & 4.67 & 126.30 & 131.77 & 2.73 \\
$\mathrm{O}_{4} \mathrm{sp}^{3}$ & 169.78 & 120.10 & 2.00 & 162.90 & 117.09 & 1.93 \\
$\mathrm{O}_{5} \mathrm{sp}^{2}$ & 146.94 & 78.67 & 4.84 & 159.30 & 102.15 & 2.86 \\
$\mathrm{O}_{6} \mathrm{sp}^{3}$ & 153.45 & 141.20 & 2.12 & 145.50 & 123.09 & 1.86 \\
$\mathrm{O}_{7} \mathrm{sp}^{3}$ & 161.31 & 112.93 & 2.07 & 171.40 & 111.41 & 1.99 \\
$\mathrm{O}_{8} \mathrm{sp}^{3}$ & 152.61 & 118.67 & 2.06 & 169.50 & 115.23 & 1.93 \\
$\mathrm{O}_{9} \mathrm{sp}^{3}$ & & & & & & \\
\end{tabular}

At level ONIOM(HF/6-311+G(d,p):AM1), value of the linearity angles $\alpha$ on the $\mathrm{O}_{5} \mathrm{sp}^{2}$ heteroatom equals $169.78^{\circ}$ and is the closest angle to the ideal value of $180^{\circ}$, the directionality angle $\beta$ equals $120.10^{\circ}$ and is the closest to the ideal angle of $120^{\circ}$, the hydrogen bond length $d$ equals $2.00 \AA$ and is the smallest (Table 1 ). Indeed, as far as the lengths of the $\mathrm{H}$ bonds (distance $d$ ) are concerned, the prac- 
tice is to consider a contact as a real $\mathrm{H}$ bond if the distance $d$ is less than the sum of the Van der Waals radius, taking $1.52 \AA$ [15], and $1.2 \AA$ [16], respectively for a contact with the oxygen and hydrogen atoms; meaning that $d \leq 2.72 \AA$. It is also known that the shorter the $\mathrm{H}$ bond length is, the stronger it is. So, according geometric parameters, $\mathrm{O}_{5} \mathrm{sp}^{2}$ heteroatom is the major hydrogen bonding site. At level ONIOM(B3LYP/6-311+G(d,p):AM1), the closest angle $\alpha, 171.40^{\circ}$, rather concerns the $\mathrm{O}_{8} \mathrm{sp}^{3}$ heteroatom, the closest angle $\beta, 108.40^{\circ}$, is found on $\mathrm{O}_{2} \mathrm{sp}^{3}$ (the ideal $\beta$ angle for $\mathrm{sp}^{3}$ oxygen equals $109.5^{\circ}$ ), and the shortest length $d, 1.86 \AA$, is found for $\mathrm{O}_{7} \mathrm{sp}^{3}$. Values of geometric parameters computed at ONIOM (B3LYP/6-311+G(d,p):AM1) level don't allow an undoubtedly conclusion about the major hydrogen bonding site.

\subsection{Energetic Parameters}

All values of enthalpy $\Delta_{r} H_{298}^{\circ}$ are negative, whatever the calculation level, meaning that all hydrogen bonding process are exothermic (Table 2). However, the lowest values are computed in the case of heteroatom $\mathrm{O}_{5} \mathrm{sp}^{2}$, respectively $-62.24 \mathrm{~kJ} / \mathrm{mol}$ and $-37.32 \mathrm{~kJ} / \mathrm{mol}$ at $\mathrm{ONIOM}(\mathrm{HF} / 6-311+\mathrm{G}(\mathrm{d}, \mathrm{p}): \mathrm{AM} 1)$ and ONIOM(B3LYP/6-311+G(d,p):AM1) levels. In the same way, negative values of free enthalpy $\Delta_{r} G_{298}^{\circ}$ are computed for $\mathrm{O}_{2} \mathrm{sp}^{3} \mathrm{O}_{3} \mathrm{sp}^{2}, \mathrm{O}_{5} \mathrm{sp}^{2}$ and $\mathrm{O}_{8} \mathrm{sp}^{3}$ at both two levels. Both at ONIOM(HF/6-311+G(d,p):AM1) and ONIOM(B3LYP/6-311+ $\mathrm{G}(\mathrm{d}, \mathrm{p}): \mathrm{AM} 1)$, these values equal respectively $-3.33 \mathrm{~kJ} / \mathrm{mol},-18.82 \mathrm{~kJ} / \mathrm{mol}$, $-19.53 \mathrm{~kJ} / \mathrm{mol}$ and $-13.02 \mathrm{~kJ} / \mathrm{mol}$. So, onthesespecificheteroatoms, Hydrogen bonding is spontaneous.

Spontaneity is much greater with the $\mathrm{O}_{5} \mathrm{sp}^{2}$ heteroatom, since the corresponding values are the lowest, i.e. $-19.53 \mathrm{~kJ} / \mathrm{mol}$ at both ONIOM (HF/6-311+ G(d,p):AM1) and ONIOM(B3LYP/6-311+G(d,p):AM1) levels. Therefore, the $\mathrm{O}_{5} \mathrm{sp}^{2}$ heteroatom gives the most stable complexes. Values of $\Delta_{r} G_{298}^{\circ}$ computed for $\mathrm{O}_{3} \mathrm{sp}^{2}$ are the closest to those computed for $\mathrm{O}_{5} \mathrm{sp}^{2}$. Those two heteroatoms, seem to be subject to mesomerism, which enhances their hydrogen bonding ability. In the other hand, $\mathrm{O}_{1} \mathrm{sp}^{3}, \mathrm{O}_{4} \mathrm{sp}^{3}, \mathrm{O}_{6} \mathrm{sp}^{3}, \mathrm{O}_{7} \mathrm{sp}^{3}$ and $\mathrm{O}_{9} \mathrm{sp}^{3}$ heteroatoms have

Table 2. Energetic parameters of Hydrogen bond complexes of mycolactone A/B. (Entropy, in $\mathrm{J} / \mathrm{mol} \cdot \mathrm{K})$.

\begin{tabular}{ccccccc}
\hline & \multicolumn{2}{c}{$\mathrm{ONIOM}(\mathrm{HF} / 6-311+\mathrm{G}(\mathrm{d}, \mathrm{p}): \mathrm{AM} 1)$} & \multicolumn{3}{c}{ ONIOM(B3LYP/6-311+G(d,p):AM1) } \\
\cline { 2 - 6 } & $\Delta_{r} H_{298}^{\circ}$ & $\Delta_{r} S_{298}^{\circ}$ & $\Delta_{r} G_{298}^{\circ}$ & $\Delta_{r} H_{298}^{\circ}$ & $\Delta_{r} S_{298}^{\circ}$ & $\Delta_{r} G_{298}^{\circ}$ \\
\hline $\mathrm{O}_{1} \mathrm{sp}^{3}$ & -19.46 & -0.12 & 16.98 & -26.20 & -014 & 16.98 \\
$\mathrm{O}_{2} \mathrm{sp}^{3}$ & -17.74 & -0.04 & -3.33 & -28.30 & -0.08 & -3.33 \\
$\mathrm{O}_{3} \mathrm{sp}^{2}$ & -29.83 & -0.03 & -18.82 & -36.63 & -0.06 & -18.82 \\
$\mathrm{O}_{4} \mathrm{sp}^{3}$ & -28.21 & -0.11 & 5.52 & -10.61 & -0.05 & 5.52 \\
$\mathrm{O}_{5} \mathrm{sp}^{2}$ & -62.24 & -0.14 & -19.53 & -37.32 & -0.06 & -19.53 \\
$\mathrm{O}_{6} \mathrm{sp}^{3}$ & -23.65 & -0.19 & 35.04 & -23.67 & -013 & 35.04 \\
$\mathrm{O}_{7} \mathrm{sp}^{3}$ & -26.14 & -0.12 & 10.07 & -4.16 & -0.04 & 10.04 \\
$\mathrm{O}_{8} \mathrm{sp}^{3}$ & -29.57 & -0.05 & -13.02 & -4.16 & -0.05 & -13.02 \\
$\mathrm{O}_{9} \mathrm{sp}^{3}$ & -18.18 & -0.12 & 19.70 & -4.26 & -0.08 & 19.70 \\
\hline
\end{tabular}


Table 3. Frequency displacements $\Delta v(\mathrm{O}-\mathrm{H})\left(\mathrm{cm}^{-1}\right)$ of Hydrogen bond complexes of mycolactone $\mathrm{A} / \mathrm{B}$

\begin{tabular}{lcc}
\hline & ONIOM(HF/6-311+G(d,p):AM1 $)$ & ONIOM(B3LYP/6-311+G(d,p):AM1) \\
\hline $\mathrm{O}_{1} \mathrm{sp}^{3}$ & 107.33 & 222.64 \\
$\mathrm{O}_{2} \mathrm{sp}^{3}$ & 127.29 & 222.71 \\
$\mathrm{O}_{3} \mathrm{sp}^{2}$ & 145.32 & 231.57 \\
$\mathrm{O}_{4} \mathrm{sp}^{3}$ & 26.19 & 195.15 \\
$\mathrm{O}_{5} \mathrm{sp}^{2}$ & 159.68 & 233.20 \\
$\mathrm{O}_{6} \mathrm{sp}^{3}$ & 117.22 & 223.10 \\
$\mathrm{O}_{7} \mathrm{sp}^{3}$ & 154.20 & 228.35 \\
$\mathrm{O}_{8} \mathrm{sp}^{3}$ & 113.56 & 198.89 \\
$\mathrm{O}_{9} \mathrm{sp}^{3}$ & 156.55 & 223.26 \\
\hline
\end{tabular}

positive values of free enthalpies, meaning that there is no possibility of spontaneous reaction for these different sites. It's noticeable that all the latter heteroatoms are $\mathrm{sp}^{3}$ hybridized. It seems that $\mathrm{sp}^{3}$ hybridized oxygen cannot be hydrogen bond major site.

\subsection{Spectroscopic Parameters}

All frequency shifts are positive (Table 3), corresponding to a decrease in the bond $\mathrm{O}-\mathrm{H}$ vibration frequency, under hydrogen bonding process. The higher the shift $\Delta v(\mathrm{O}-\mathrm{H})$ is, the stronger the Hydrogen bong will be. Highest values correspond to $\mathrm{O}_{5} \mathrm{sp}^{2}$ heteroatom, i.e. $159.68 \mathrm{~cm}^{-1}$ and $233.20 \mathrm{~cm}^{-1}$ respectively at $\operatorname{ONIOM}(\mathrm{HF} / 6-311+\mathrm{G}(\mathrm{d}, \mathrm{p}): \mathrm{AM} 1)$ and $\mathrm{ONIOM}(\mathrm{B} 3 \mathrm{LYP} / 6-311+\mathrm{G}(\mathrm{d}, \mathrm{p}): \mathrm{AM} 1)$ levels. Spectroscopic parameters designate then the $\mathrm{O}_{5} \mathrm{sp}^{2}$ oxygen atom as the major Hydrogen bonding site.

\section{Conclusion}

ONIOM two layers method has been successfully used to identify mycolactone $\mathrm{A} / \mathrm{B}$ hydrogen bonding major sites. This compound possesses up to nine oxygen heteroatoms, all $\mathrm{sp}^{2}$ or $\mathrm{sp}^{3}$ hybridized. Geometric, energetic and spectroscopic parameters have been computed at both $\operatorname{ONIOM}(\mathrm{HF} / 6-311+\mathrm{G}(\mathrm{d}, \mathrm{p}): \mathrm{AM} 1)$ and ONIOM(B3LYP/6-311+G(d,p):AM1) levels. Results show that $\mathrm{sp}^{2}$ hybridized oxygen is the major hydrogen bonding site and then $\mathrm{sp}^{3}$ hybridized oxygen is unlikely subject to hydrogen bonding. Two $\mathrm{sp}^{2}$ oxygen atoms, $\mathrm{O}_{3} \mathrm{sp}^{2}$ and $\mathrm{O}_{5} \mathrm{sp}^{2}$, involved in mesomerism process are the very major sites. Our analysis has permit to undoubtedly designate the major site as $\mathrm{O}_{5} \mathrm{sp}^{2}$ atom. Annihilating such a site would render the action of Mycobacterium ulcerans ineffective, assuming that all intermolecular interactions will occur on the same site as Hydrogen bonding.

\section{References}

[1] WHO (2008) Buruli Ulcer: Progress Report, 2004-2008, Weekly Epidemiological Record, 83, 145-154. http://www.who.int/wer 
[2] Young, V.R. (1970) The role of skeletal and cardiac muscle in the regulation of protein metabolism. In: Munro, H.N., Ed., Mammalian Protein Metabolism, Vol. 4, Academic Press, New York, 587-674. https://doi.org/10.1016/b978-0-12-510604-7.50018-9

[3] Marston, B.J., Diallo M.O. and Horsburgh Jr., C.R. (1995) Emergence of Buruli Ulcer Disease in the Daloa Region of Côte d'Ivoire. American Society of Tropical Medicine and Hygiene, 52, 219-224. https://doi.org/10.4269/ajtmh.1995.52.219

[4] Torrado, E., Adusumilli, S., Fraga, A.G., Small, P.L. and Castro, A.G. (2007) Mycolactone-Mediated Inhibition of Tumor Necrosis Factor Production by Macrophages Infected with Mycobacterium ulcerans Has Implications for the Control of Infection. Infection and Immunity, 75, 3979-3988.

https://doi.org/10.1128/IAI.00290-07

[5] Stanford, J.L., Revill, W.D., Gunthorpe, W.J. and Grange, J.M. (1974) The Production and Preliminary Investigation of Burulin, a New Skin Test Reagent for $\mathrm{Myco}$ bacterium ulcerans. Journal of Hygiene (London), 74, 7-16. https://doi.org/10.1017/S0022172400046659

[6] George, K., Chatterjee, M., Gunawardana, D., Welty, G., Hayman, D., Lee, J. and Small, P.R. (1999) Mycolactone: A Polyketide Toxin from Mycobacterium ulcerans Required for Virulence. Science AAAS, 283, 854-857.

https://doi.org/10.1126/science.283.5403.854

[7] Rablen, P.R., Lockman, J.W. and Jorgensen, W.L. (1998) Ab Initio Study of Hydrogen-Bonded Complexes of Small Organic Molecules with Water. The Journal of Physical Chemistry A, 102, 3782-3797. https://doi.org/10.1021/jp980708o

[8] Jeffrey, G.A. and Saenger, W. (1991) Hydrogen Bonding in Biological Structures. Springer-Verlag, Berlin. https://doi.org/10.1007/978-3-642-85135-3

[9] Desiraju, G.R. (1997) Designer Crystals: Intermolecular Interactions, Network Structures and Supramolecular Synthons. Chemical Communications, 1475-1482. https://doi.org/10.1039/a607149j

[10] Aakeröy, C.B. (1997) An Infinite Hydrogen-Bonded Sheet in Guanidinium Trifluoromethanesulfonate. Actacryst, 53, 569-586.

[11] Berthelot, M., Laurence, C., Safar, M. and Besseau, F. (1998) Hydrogen-Bond Basicity pKHB Scale of Six-Membered Aromatic N-Heterocycles. Journal of the Chemical Society, Perkin Transactions, 2, 283-290.

https://doi.org/10.1039/a706696a

[12] Gaussian 03, Revision C.01, Frisch, M.J., Trucks, G.W., Schlegel, H.B., Scuseria, G.E., Robb, M.A., Cheeseman, J.R., Montgomery, Jr., J.A., Vreven, T., Kudin, K.N., Burant, J.C., Mil-lam, J.M., Iyengar, S.S., Tomasi, J., Barone, V., Mennucci, B., Cossi, M., Scalmani, G., Rega, N., Petersson, G.A., Nakatsuji, H., Hada, M., Ehara, M., Toyota, K., Fukuda, R., Hasegawa, J., Ishida, M., Nakajima, T., Honda, Y., Kitao, O., Nakai, H., Klene, M., Li, X., Knox, J.E., Hratchian, H.P., Cross, J.B., Adamo, C., Jaramillo, J., Gomperts, R., Stratmann, R.E., Yazyev, O., Austin, A.J., Cammi, R., Pomelli, C., Ochterski, J.W., Ayala, P.Y., Morokuma, K., Voth, G.A., Salvador, P., Dannenberg, J.J., Zakrzewski, V.G., Dapprich, S., Daniels, A.D., Strain, M.C., Farkas, O., Malick, D.K., Rabuck, A.D., Raghavachari, K., Foresman, J.B., Ortiz, J.V., Cui, Q., Baboul, A.G., Clifford, S., Cioslowski, J., Stefanov, B.B., Liu, G., Liashenko, A., Piskorz, P., Komaromi, I., Martin, R.L., Fox, D.J., Keith, T., Al-Laham, M.A., Peng, C.Y., Nanayakkara, A., Challacombe, M., Gill, P.M.W., Johnson, B., Chen, W., Wong, M.W., Gonzalez, C. and Pople, J.A. (2004) Gaussian, Inc., Wallingford.

[13] Desiraju, G.R. and Steiner, T. (1999) The Weak Hydrogen Bond in Structural Chemistry and Biology. The Weak Hydrogen Bond in Structural Chemistry and Biolo- 
gy, Oxford University Press, Oxford.

[14] Jeffrey, G.A. and Saenger, W. (1991) Hydrogen Bonding in Biological Structures. Springer, Berlin. https://doi.org/10.1007/978-3-642-85135-3

[15] Jorly, J. and Eluvathingal, D.J. (2007) Red-, Blue-, or No-Shift in Hydrogen Bonds: A Unified Explanation. Journal of the American Chemical Society, 129, 4620-4632. https://doi.org/10.1021/ja067545z

[16] Bondi, A. (1964) Van der Waals Volumes and Radii. Journal of Physical Chemistry, 68, 441-451. https://doi.org/10.1021/j100785a001

Submit or recommend next manuscript to SCIRP and we will provide best service for you:

Accepting pre-submission inquiries through Email, Facebook, LinkedIn, Twitter, etc. A wide selection of journals (inclusive of 9 subjects, more than 200 journals) Providing 24-hour high-quality service User-friendly online submission system Fair and swift peer-review system Efficient typesetting and proofreading procedure Display of the result of downloads and visits, as well as the number of cited articles Maximum dissemination of your research work

Submit your manuscript at: http://papersubmission.scirp.org/ Or contactcc@scirp.org 